\title{
Manganese in the nutrition and metabolism of the pullet
}

\author{
2.* The manganese contents of the tissues of pullets \\ given diets of high or low manganese content
}

\author{
By J. W. MATHERS† AND R. HILL \\ Royal Veterinary College, University of London
}

(Received 28 December I967-Accepted 8 fuly 1968)

\begin{abstract}
I. Groups of pullets were given a diet of high (106-107 $\mu \mathrm{g} / \mathrm{g}$ ) or low (6-7 $\mu \mathrm{g} / \mathrm{g}$ ) manganese content and killed either before sexual maturity, at the point-of-lay or after a 6 - to 7 -month laying period. The birds were dissected into six tissue fractions: skeleton, liver, kidney, ovary and oviduct, skin and feathers, and muscle with remaining tissue. Total $\mathrm{Mn}$ and concentration of $\mathrm{Mn}$ as $\mu \mathrm{g} / \mathrm{g}$ dry fat-free tissue were determined for each fraction.

2. There were no differences in live weight attributable to level of dietary $\mathrm{Mn}$, and no differences in egg production.

3. Mean total body $\mathrm{Mn}$ varied among groups over a fairly narrow range $\left(528-73^{8} \mu \mathrm{g}\right)$, with the exception of birds given the high-Mn diet throughout the experiment, in which the mean was $2319 \mu \mathrm{g}$. This represented an increase in $\mathrm{Mn}$ content during egg laying of $244 \%$. There was no significant difference in the Mn content of birds given the low-Mn diet whether they were killed at the point-of-lay or after the laying period.

4. The effects of treatment on the weight of Mn in each of the tissue fractions are described. The very large increase in total $\mathrm{Mn}$ that occurred during egg production in birds given the high-Mn diet was accounted for largely by the increase in skin and feathers (1072 $\mu \mathrm{g} \mathrm{Mn).}$

5. In general terms, the Mn content of liver, kidney and ovary and oviduct together constituted only just over 10 \% of total body $\mathrm{Mn}$, the remainder being distributed about equally among skeleton, skin and feathers, and muscle with remaining tissue.

6. There was a close parallel between the concentration of $\mathrm{Mn}$ of a tissue and the total weight of $\mathrm{Mn}$ it contained except in certain instances when stage of maturity or egg production influenced weight of the tissue.

7. The effects of treatments on the Mn contents of these birds are discussed in relation to the retention of dietary $\mathrm{Mn}$, and the withdrawal from and accumulation of $\mathrm{Mn}$ in individual tissues and the whole body.
\end{abstract}

It has been suggested that a high proportion of total body manganese is present in the skeleton and that this constitutes a substantial store of the element (Underwood, I962), but no information is available from which the proportion in the skeleton could be calculated, nor to show that skeletal Mn can be withdrawn at times of shortage. That the liver may be an important storage site for Mn was indicated by the report of Bolton (1955), who found that the Mn content of the livers of laying birds was greater than that of non-laying birds and that a concentration similar to that in laying birds occurred in immature pullets after the administration of sex hormones.

The object of the experiment reported here was to obtain information on the accumulation in and withdrawal of $\mathrm{Mn}$ from certain tissues and whole body of pullets by analysing the tissues of birds killed at different stages of egg production and given a diet of high or low Mn content.

* Paper no. I : Br. F. Nutr. (1968), 22, 625.

$\uparrow$ Present address: John Thompson and Sons, Belfast. 


\section{EXPERIMENTAL}

Forty-six light hybrid pullets were reared on a commercial growers diet, and then divided randomly into six groups at 18 weeks of age. Seven birds were killed at I 8 weeks of age (group I), seventeen were given the high-Mn diet, ten being killed at the point-of-lay (group $\mathrm{H}$ ) and seven after $6-7$ months of egg production (group $\mathrm{HH}$ ). Fifteen birds were given the low-IMn diet, eight being killed at the point-of-lay (group L) and seven after 6-7 months of egg production (group LL). A further seven birds were given the high-Mn diet to point-of-lay followed by the low-Mn diet during the same period of egg production (group HL). Groups HH, LL and HL were the birds described in Expt 3 of Hill \& Mathers (I968).

The basal low-Mn diet described earlier (Hill, $\mathrm{I} 965 b$ ) contained $6-7 \mu \mathrm{g} \mathrm{Mn} / \mathrm{g}$, and the high-Mn diet was prepared by adding manganese carbonate to provide a further $100 \mu \mathrm{g} \mathrm{Mn} / \mathrm{g}$.

The tissues of the birds were separated for analysis into six fractions: skeleton, liver, kidney, ovary and oviduct, skin and feathers, and muscle with remaining tissue. The tissue, or a known proportion of it, was dried and extracted with light petroleum (b.p. $40-60^{\circ}$ ). The dry fat-free tissues were ground and ashed, or a sample was taken for ashing. The desirability of washing the skin and feathers to remove possible surface contamination was considered but rejected; the matter is discussed later. $\mathrm{Mn}$ was determined in the ash by the standard permanganate method (Association of Official Agricultural Chemists, 1945). The total Mn content of each tissue, of the whole bird, and the concentration of $\mathrm{Mn}$ in the dry fat-free tissues were calculated.

\section{RESULTS}

\section{Live weights and egg production}

These values are given in Table 1 . The birds increased in live weight during the 7 weeks before egg laying began and during the subsequent 7 months, but there were no consistent effects of level of dietary Mn on live weight.

All the groups of birds that laid for 6-7 months (HH, LL and HL) produced at a high level, and dietary treatment had no significant effect on egg production.

\section{Total Mn content of tissues}

Mean values for individual tissues, as well as for the whole body, are given in Table 2.

Total body Mn was less than I mg in all groups except HH. The sexually immature pullets (group I) contained $73^{8} \mu \mathrm{g} \mathrm{Mn}$ : they were killed about 7 weeks before egg laying began in the remainder of the birds. Birds given the high-Mn diet to the point-of-lay (group $\mathrm{H}$ ) contained a slightly, but not significantly, smaller weight of Mn $(677 \mu \mathrm{g})$, than those of group I $(P>0.05)$. Birds given the low-Mn diet to the point-of-lay (group L) contained significantly less $\mathrm{Mn}(527 \mu \mathrm{g})$ than those of group I $(P<0.01)$. Values for groups $\mathrm{H}$ and $\mathrm{L}$ represent decreases in Mn content during sexual maturation of $8 \%$ and $29 \%$ respectively. 
Birds that continued on the high-Mn diet during 6-7 months of egg laying (group $\mathrm{HH})$ contained a very much larger amount of $\mathrm{Mn}(23 \mathrm{I} 9 \mu \mathrm{g})$ than corresponding birds killed at the point-of-lay (group $\mathrm{H}, 677 \mu \mathrm{g}$ ): the difference was highly significant statistically and represented an increase in Mn content during egg laying of $244 \%$.

Birds that continued on the low-Mn diet for the egg-laying period (group LL) contained $55^{2} \mu \mathrm{g} \mathrm{Mn}$, slightly more than those on the same diet killed at the point-oflay (group L, $527 \mu \mathrm{g}$ ), but the difference was not significant. The difference corresponds to an increase in Mn content of $5 \%$.

Table 1. Mean values for live weight and percentage egg production of the pullets

\begin{tabular}{|c|c|c|c|c|c|}
\hline $\begin{array}{l}\text { Treat- } \\
\text { ment } \\
\text { group }\end{array}$ & Treatment & $\begin{array}{l}\text { No. } \\
\text { of } \\
\text { birds }\end{array}$ & $\begin{array}{l}\text { Live } \\
\text { weight } \\
\text { when } \\
\text { killed } \\
\text { (g) }\end{array}$ & $\begin{array}{l}\text { No. of } \\
\text { days } \\
\text { in lay }\end{array}$ & $\begin{array}{l}\text { Egg } \\
\text { produc- } \\
\text { tion } \\
(\%)\end{array}$ \\
\hline I & Sexually immature birds killed at 18 weeks of age & 7 & I439 & - & 一 \\
\hline $\mathbf{H}$ & $\begin{array}{l}\text { Birds killed at point-of-lay, after receiving the } \\
\text { high-Mn diet from I } 8 \text { weeks of age }\end{array}$ & ro & 1647 & - & $\cdots$ \\
\hline $\mathrm{L}$ & $\begin{array}{l}\text { Birds killed at point-of-lay, after receiving the } \\
\text { low-Mn diet from } x 8 \text { weeks of age }\end{array}$ & 8 & I656 & 一 & - \\
\hline $\mathrm{HH}$ & $\begin{array}{l}\text { Birds killed after } 7 \text { months of egg production having } \\
\text { received the high-Mn diet from } 18 \text { weeks of age }\end{array}$ & 7 & І869 & 200 & 86 \\
\hline $\mathbf{L} \mathbf{L}$ & $\begin{array}{l}\text { Birds killed after } 7 \text { months of egg production having } \\
\text { received the low-Mn diet from I } 8 \text { weeks of age }\end{array}$ & 7 & I854 & 207 & $\mathbf{8}_{3}$ \\
\hline $\mathrm{HL}$ & $\begin{array}{l}\text { Birds killed after } 7 \text { months of egg production having } \\
\text { received the high-Mn diet from i } 8 \text { weeks of age to } \\
\text { point-of-lay and the low-Mn diet during } 7 \text { months of } \\
\text { egg production }\end{array}$ & 7 & I943 & 202 & 83 \\
\hline & SE of difference between means & & - & $\pm 4 \cdot 6 \mathrm{I}$ & $\pm 3 \cdot 89$ \\
\hline
\end{tabular}

Changing the level of dietary Mn from high to low at the point-of-lay (group HL) gave a total body $\mathrm{Mn}$ value of $577 \mu \mathrm{g}$, not significantly lower than for corresponding birds killed at the point-of-lay (group $\mathrm{H}, 677 \mu \mathrm{g}$ ), but a difference that represents a decrease during egg laying of $15 \%$.

The weight of Mn in the skeleton (Table 2) of birds given the high-Mn diet during egg laying (group $\mathrm{HH})$ was very large $(564 \mu \mathrm{g})$ and significantly greater $(P<0.00 \mathrm{r})$ than weights of the remaining five groups (126-180 $\mu \mathrm{g})$, among which there were no significant differences. There was a fairly close relationship between the Mn content of the skeleton and of the whole body, skeletal Mn constituting about $25 \%$ of the total for all treatments.

Total liver Mn contents in groups given the low-Mn diet (L, LL and HL) were similar (30.6, 40.5 and $35^{\circ} 6 \mu \mathrm{g}$ respectively) and significantly lower than in the re-

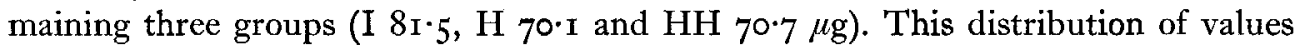
with treatment contrasts markedly with that for the skeleton; it is illustrated by the wider range of values for liver $\mathrm{Mn}$ expressed as a percentage of the total $(3 \cdot \mathrm{I}$ for group $\mathrm{HH}$ to I I I for group I). The exceptionally low value for group $\mathrm{HH}(3 \cdot \mathrm{I} \%)$ was caused by the liver content remaining fairly constant while total body $\mathrm{Mn}$ increased greatly. 


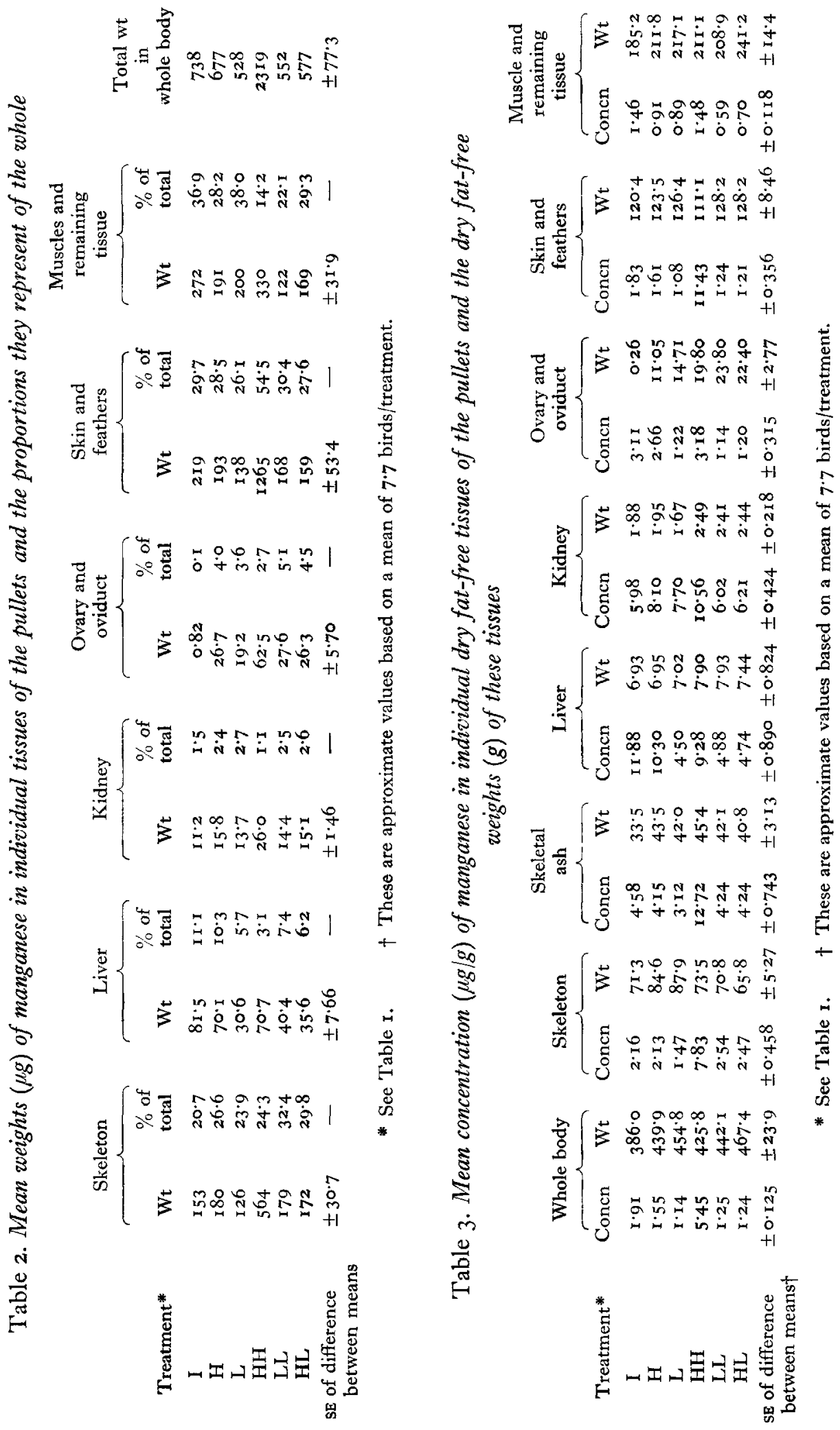


The Mn content of kidney and ovary and oviduct varied with treatment somewhat similarly to that of the skeleton; values for group HH were considerably greater than for the other groups. The Mn content of skin and feathers also gave similar treatment differences to the skeleton but the difference between group $\mathrm{HH}$ and the remaining groups was much larger than for other tissues. The Mn content of the skin and feathers of group $\mathrm{HH}$ was six to nine times greater than that of other treatment groups, while for the skeleton, kidney, and ovary and oviduct the corresponding differences were only two- to three-fold. The very large skin and feather Mn content of group $\mathrm{HH}$ ( $1265 \mu \mathrm{g}$ ) represents an extremely high proportion $(54.5 \%$ ) of the total body $\mathrm{Mn}$. The possibility that surface contamination contributed to this value is discussed later.

The Mn content of muscle and remaining tissues did not follow closely the pattern of treatment effects described for other tissues. Both groups killed at the point-of-lay $(\mathrm{H}$ and $\mathrm{L}$ ) contained significantly less $\mathrm{Mn}$ than the initial group (I), and the two low-Mn groups killed at the end of the egg-laying period (LL and HL) contained slightly less than those killed at point-of-lay ( $H$ and $L$ ); also unlike other tissues except the liver, the value for muscle and remaining tissue of group $\mathrm{HH}(330 \mu \mathrm{g})$ was only moderately greater than those of other groups and not significantly different from that of group I $(272 \mu \mathrm{g})$.

From values for individual tissues calculated as percentages of total body $\mathrm{Mn}$, it is evident that fairly wide variations occurred between treatments in the proportion of the total contributed by a particular tissue, but in general it will be noted that $\mathrm{Mn}$ in liver, kidney, and ovary and oviduct constituted only just over $10 \%$ of the total and the remainder was found in approximately equal proportions in the skeleton, the skin and feathers, and in the muscle with remaining tissue.

\section{Mn concentration}

Mean concentrations as $\mu \mathrm{g} / \mathrm{g}$ dry fat-free tissue are given in Table 3 , together with weights of tissue and the standard errors of differences between two means. In general, the effects of treatment on the weights of individual tissues were small, and were related to stage of maturity or egg laying, not to level of dietary Mn. In consequence of the generally small effects on weight of tissue, differences in concentration of $\mathrm{Mn}$ between the treatment groups reflected fairly closely those described above for weight of $\mathrm{Mn}$.

The mean concentration of $\mathrm{Mn}$ in dry fat-free tissue of the whole body varied between $\mathrm{I} \cdot \mathrm{I} 4$ and $\mathrm{I} \cdot 9 \mathrm{I} \mu \mathrm{g} / \mathrm{g}$ for all groups except $\mathrm{HH}$, which had a much higher value $(5.45 \mu \mathrm{g} / \mathrm{g})$. Among groups in the lower range of values, group I ( $\cdot 9 \mathrm{I} \mu \mathrm{g} / \mathrm{g}) \mathrm{had}$ a significantly greater concentration than the remainder.

The concentration in dry fat-free bone was greater than in the whole body, the difference varying from twice as great for groups LL and HL to only slightly greater for group I. The effects of treatment on skeletal Mn were in some instances greater in terms of concentration than in terms of weight, there being differences between treatments in weight of dry fat-free bone and in percentage of ash. A marked example of this effect is observed when values for group $\mathrm{H}$ are compared with those for HL: total $\mathrm{Mn}$ contents were similar, I 80 and $\mathrm{I}_{72} \mu \mathrm{g}$ respectively, but concentrations in dry fat-free bone differed significantly $(2 \cdot 13$ and $2.47 \mu \mathrm{g} / \mathrm{g}$ respectively), while in 
consequence of a substantial difference in percentage of ash ( $\mathrm{H}_{52} \%$ and $\mathrm{HL} 62 \%$ ) concentrations in ash were similar ( $4 \cdot 15$ and $4.24 \mu \mathrm{g} / \mathrm{g}$ respectively).

In the liver, concentration of Mn was generally high $(4 \cdot 5-1 \mathrm{I} \cdot 9 \mu \mathrm{g} / \mathrm{g})$ in comparison with that of the whole body, and kidney Mn concentration was also high (6.0-10.6 $\mu \mathrm{g} /$ g). There were differences in the weight of dry fat-free kidneys, birds killed after 6-7 months of egg production (groups HH, LL and HL) having significantly heavier kidneys than those killed earlier (groups $\mathrm{I}, \mathrm{H}$ and $\mathrm{L}$ ), giving significantly different concentrations of $\mathrm{Mn}$ in some instances where none existed for weight. A striking example of this effect occurred between groups L and LL: weights of Mn were similar ( 13.7 and $14.4 \mu \mathrm{g}$ ), but weights of tissue, $\mathrm{x} .67$ and $2.4 \mathrm{I} \mathrm{g}$, and concentrations, 7.70 and $6.02 \mu \mathrm{g} / \mathrm{g}$ respectively, differed significantly.

The ovary and oviduct were not rich in $\mathrm{Mn}$, the concentration being $\mathrm{I} \cdot \mathrm{I}-3 \cdot 2 \mu \mathrm{g} / \mathrm{g}$. There was a tendency for the weight of dry fat-free tissue to be greater for low-Mn groups than for the corresponding high-Mn groups, giving a greater difference between $\mathrm{H}$ and $\mathrm{L}$ groups for concentration than for weight of $\mathrm{Mn}$.

The concentration of $\mathrm{Mn}$ in skin and feathers was low, $\mathrm{I} \cdot \mathrm{I}-\mathrm{I} \cdot 8 \mu \mathrm{g} / \mathrm{g}$ for all groups except $\mathrm{HH}$, for which the value was remarkably high, II $4 \mu \mathrm{g} / \mathrm{g}$. In muscle and remaining tissue $\mathrm{Mn}$ concentration was low for all groups, $0 \cdot 6-\mathrm{I} \cdot 5 \mu \mathrm{g} / \mathrm{g}$. In this tissue, as with liver, and ovary and oviduct, but unlike bone, kidney, and skin and feathers, the concentration of $\mathrm{Mn}$ for birds given the high-Mn diet throughout the experiment (group $\mathrm{HH}, \mathrm{I} \cdot 48 \mu \mathrm{g} / \mathrm{g}$ ) was no greater than for birds killed at the start of the experiment (group I, I*46 $\mu \mathrm{g} / \mathrm{g}$ ).

\section{DISCUSSION}

At the outset it is necessary to appreciate the problem alluded to earlier, namely the possibility that the values found for the Mn content of skin and feathers may be in error owing to surface contamination, by food in particular. The value most suspect is for group $\mathrm{HH}, \mathrm{II} \cdot 43 \mu \mathrm{g} / \mathrm{g}$ dry fat-free tissue, that was very high by comparison with values of $\mathrm{r} \cdot 08-\mathrm{r} \cdot 83 \mu \mathrm{g} / \mathrm{g}$ for the remaining five groups. The $\mathrm{HH}$ birds had received the high-Mn diet longer (about 2,50 days) than any other birds given the same diet (about $5 \circ$ days) and therefore the opportunity for contamination was greatest. However if this were an explanation of the high concentration for these birds some tendency for contamination with the high-Mn diet might have been expected in the skin and feathers of group $\mathrm{H}$ birds given this diet for about $5^{\circ}$ days before being killed at point-of-lay, but their mean value $(\mathrm{I} \cdot 6 \mathrm{r} \mu \mathrm{g} / \mathrm{g})$ represented a decrease in concentration, the initial group (I) having $\mathrm{I} \cdot 83 \mu \mathrm{g} / \mathrm{g}$.

From two birds, not part of this experiment, that had been laying for about 6 months on a diet similar to the high-Mn diet used here (100 $\mu \mathrm{g}$ added $\mathrm{Mn} / \mathrm{g}$ ) the skin and feathers of each bird were halved along the mid-line and one half washed five times with water and the other half left unwashed. The washed samples contained $2 \cdot 72$ and $3.27 \mu \mathrm{g} / \mathrm{g}$ dry fat-free tissue, considerably less than the unwashed samples 10.57 and $6.92 \mu \mathrm{g} / \mathrm{g}$, and suggested that the high values were given largely by surface contamination, but it is known that $\mathrm{Mn}$ does not form stable bonds with organic compounds (Chemical Society, 1957; Hill, 1965a) and it is possible that some at least of the Mn 
removed by washing could be properly regarded as part of the tissue. It was decided to analyse unwashed samples in the present study, since there was no way of determining whether washing gave a more or a less accurate assessment of Mn content. It may be noted that when the balance method is used to determine retention any contamination of skin and feathers that occurs from the feed is recorded as part of the retained fraction. Two further points may be mentioned that support the validity of the high values obtained for group HH. First, for these to arise from feed contamination would require just over Io $g$ of the feed to be adhering to the skin and feathers, whereas no gross contamination of this order was observed, and secondly, individual values for that group were fairly uniform $(10.08-13.30 \mu \mathrm{g} / \mathrm{g}$ ) whereas a larger range might be expected if marked contamination had occurred.

The results obtained with this comparative slaughter method can be discussed in terms of changes in composition, or of gains or losses of $\mathrm{Mn}$, on the assumption that birds killed at one stage were representative of the birds on the same dietary treatment killed later.

An important premise underlying this experiment was that, when egg laying begins in birds given a high-Mn diet, the tissues contain a large potential reserve of Mn for use during egg production when the diet has a low Mn content. It is difficult to know what quantity of Mn would constitute a 'large reserve', but at the point-of-lay in birds given the high-Mn diet the total body Mn content was surprisingly small$677 \mu \mathrm{g}$. If the Mn content of an egg is taken as Io $\mu \mathrm{g}$ (Hill \& Mathers, 1968), this amount represents about seventy eggs, but when similar birds were changed to a low-Mn diet at the point-of-lay they contained $577 \mu \mathrm{g}$ after the production of 170 eggs, a loss of only roo $\mu \mathrm{g}$ Mn (the Mn content of about ten eggs). This suggests either that the low-Mn diet was able to supply almost sufficient Mn for egg production ( $1700 \mu \mathrm{g}: 1600 \mu \mathrm{g}$ from the diet and $100 \mu \mathrm{g}$ from the tissues), or that only I00 $\mu \mathrm{g}$ could be withdrawn without seriously disturbing metabolism and that a smaller amount than Io $\mu \mathrm{g}$ reached each egg. This second possibility is supported by results for the other two low-Mn groups: they both contained similar amounts of Mn $(528$ and $552 \mu \mathrm{g})$ to that given above, though one was for birds given the low-Mn diet for only $5 \circ$ days before the point-of-lay, and the other for birds given the low-Mn diet for the whole experiment (50 days before laying and a 200-day laying period). These considerations suggest that at the point-of-lay the potential reserve of $\mathrm{Mn}$ in the bird is fairly small, probably the total Mn content of about ten eggs. In this experiment a low-Mn diet was imposed only at the point-of-lay or a few weeks before. Had a change from high- to low-Mn diet been made after a period of 6-7 months egg production, the picture might have been quite different, since the birds accumulated a very large amount of $\mathrm{Mn}$ during such a period of egg production ( $\left.\mathrm{I}_{4} 2 \mu \mathrm{g}\right)$.

The decrease in $\mathrm{Mn}$ content ( $100 \mu \mathrm{g}$ ) that occurred during egg laying in birds given the high-Mn diet to the point-of-lay and the low-Mn diet during egg laying was largely from the liver (one-third) and skin and feathers (one-third), and most of the rest from the muscle and remaining tissue. Only $8 \mu \mathrm{g}$ of the $100 \mu \mathrm{g}$ was contributed by the skeleton, an unexpectedly small proportion in view of the deduction made by Underwood (1962) that skeletal Mn represents a substantial store of the element. For 
all tissues other than liver, there was an accumulation of $\mathrm{Mn}$ during egg laying in birds given the high-Mn diet. In some tissues this increase was large (skin and feathers ( $1072 \mu \mathrm{g}$ ) and skeleton $\left(3^{8} \mu \mu \mathrm{g}\right)$ ), and had these birds been subsequently given the low-Mn diet for a period of egg production some of this Mn may have become available. The liver was exceptional in that no accumulation occurred during egg laying on the high-Mn diet, and the maximum amount available from this organ was about $35 \mu \mathrm{g}$.

The total content of $\mathrm{Mn}$ in the liver was of the same order as that found by Bolton (1955), but this author found a lower value for non-laying than for laying and oestrogentreated immature birds, whereas the livers of the immature birds in the present experiment contained more $\mathrm{Mn}$ than those of any of the sexually mature groups.

A consideration of changes in total body $\mathrm{Mn}$ provides evidence of greater retention of dietary Mn during egg laying than before the point-of-lay. In birds given the highMn diet an increase of $1642 \mu \mathrm{g} \mathrm{Mn}$ occurred during the 200-day laying period, and 170 eggs were laid representing a similar weight of $M n(170 \times 10 \mu g)$, giving a total retention of about $3200 \mu \mathrm{g}$. At this rate, $800 \mu \mathrm{g}$ would be retained in 50 days, but birds given the same diet for 50 days before egg laying gained no $\mathrm{Mn}$ : indeed a small but non-significant loss occurred (6r $\mu \mathrm{g})$. Values for birds given the low-Mn diet provide similar evidence for a greater retention during egg laying than before sexual maturity, and the increase in Mn content of eggs observed in a previous experiment during a 2-month laying period indicated that retention increased as the laying period advanced (Hill \& Mathers, 1968).

As estimated above, birds in this experiment given the high-Mn diet retained about I $6 \mu \mathrm{g} \mathrm{Mn} /$ day during egg production. If a higher value is taken for the Mn content of an egg (Underwood, 1962 ) this may be increased to $25 \mu \mathrm{g}$, and if the daily feed intake be taken as $100 \mathrm{~g}$ (unpublished findings) $25 \mu \mathrm{g}$ represents about $0.25 \%$ of intake. In an earlier short-term experiment in which radioactive $\mathrm{Mn}$ was administered to birds that had been given a high-Mn diet, $0.35 \%$ of a dose was found in the liver (Hill I965): this represents about $\mathrm{I} \%$ in the whole bird (Mathers \& Hill, I967). These estimates made by different methods do not tally exactly, but they are fairly close by comparison with the $32 \%$ ( $1600 \mu \mathrm{g} /$ day) retention obtained from a balance experiment by Brown \& McCracken (1965). No explanation of this apparent discrepancy can be given, though the difficulties involved in the balance method for mineral studies discussed by Duncan (1967) may be relevant.

From observations described earlier on the shells of eggs produced by birds in the present experiment (Hill \& Mathers, I968), and the results for Mn given here, it appears that, although at the start of egg laying shell thickness was related to tissue Mn content, this was not so after 6 months of egg laying. The first shells produced by high-Mn and low-Mn groups had thicknesses of 77.6 and $70.0 \mathrm{mg} / \mathrm{cm}^{2}$ respectively, and corresponding concentrations of $\mathrm{Mn}$ in ovary and oviduct were 2.66 and $\mathrm{I} .22 \mu \mathrm{g} / \mathrm{g}$, while shells produced after 6 months had thicknesses of 73.3 in group HH, 68.0 in group $\mathrm{LL}$ and 74.8 in group HL, and corresponding Mn concentrations were $3 \cdot 18$, $\mathrm{I} \cdot \mathrm{I}_{4}$ and $\mathrm{I} \cdot 20 \mu \mathrm{g} / \mathrm{g}$ respectively. Further, on considering changes in shell thickness and tissue $\mathrm{Mn}$ content for birds given the high-Mn diet throughout the experiment, shell thickness tended to decrease with time and tissue Mn to increase. 
The efficient technical assistance of Mrs Ann Hosier and Mrs R. Docking is gratefully acknowledged. We also thank the British Egg Marketing Board for financial support, and B. J. Ingrams Ltd, distributors of Shaver Starcross pullets, for supplying the experimental birds.

\section{REFERENCES}

Association of Official Agricultural Chemists (1945). Official and Tentative Methods of Analysis, 6th ed., p. 120. Washington, DC: Association of Official Agricultural Chemists.

Bolton, W. (1955). Br. F. Nutr. 9 , I70.

Brown, W. O. \& McCracken, K. J. (1965). F. agric. Sci., Camb. 64, 305.

Chemical Society (1957). Stability Constants of Metal Ion Complexes with Solubility Products of Inorganic Substances. Vol. I. Organic Ligands, pp. 5, 76. London: The Chemical Society. Spec. Publ. no. 6.

Duncan, D. L. (1967). Proc. Nutr. Soc. 26, I02.

Hill, R. ( $965 a)$. Br. F. Nutr. 19, I63.

Hill, R. $\left(\right.$ 1965 $\left._{5}\right)$. Br. F. Nutr. 19, 171.

Hill, R. \& Mathers, J. W. (1968). Br. F. Nutr. 22, 625.

Mathers, J. W. \& Hill, R. (1967). Br. F. Nutr. 21, 5 I3.

Underwood, E. J. (1962). Trace Elements in Human and Animal Nutrition, and ed., ch. 7. London: Academic Press Inc. 